\title{
Fobia Wajib Pajak Untuk Mengungkapkan Harta
}

\author{
Fellyana Nadia Putri ${ }^{1}$, Umaimah ${ }^{2 *}$ \\ ${ }^{1,2}$ Universitas Muhammadiyah Gresik, Jl. Sumatra 101, Gresik, Indonesia.
}

http://

\section{Abstract}

This study aims to reveal the meaning of phobia that taxpayers feel in disclosing their assets. This study used a qualitative method with a transcendental phenomenological approach by Edmund Husserl. The number of informants in this study was three people, including taxpayers, tax authorities, and tax consultants. Data collection was carried out by conducting in-depth interviews with the three informants. The meaning of the phobia revealed is that the taxpayer's phobia in disclosing assets is a form of calculating profit and loss and reflects the taxpayer's faith.

\section{Type of Paper: Empirical}

Key Words: The meaning of phobias, informant awareness, calculation of profit and loss, a reflection of faith

\section{Pengantar}

Pajak dapat diklaim sebagai jantung perekonomian Indonesia pasalnya pada saat ini menurut Data Kementerian Keuangan Republik Indonesia penerimaan negara yang bersumber dari pajak sebesar 1.865,7 T. Namun fenomena yang berkembang dari dulu sampai saat ini adalah adanya pola sikap perlawanan yang tercermin dari tingkat kepatuhan wajib pajak dalam menyampaikan SPT Tahunan (Kesuma, 2016). Salah satu perlawanannya adalah aset yang dimiliki oleh wajib pajak tidak dilaporkan sepenuhnya dalam SPT Tahunannya. Wajib pajak merasa takut untuk melaporkan hartanya, mereka takut apabila pelaporan harta pada SPT Tahunan akan berdampak pada pajaknya. Padahal sudah seharusnya wajib pajak memiliki kesadaran yang tinggi untuk mematuhi kewajiban perpajakan khususnya dalam pelaporan harta (Kuncoro, 2018).

Berbagai kebijakan diambil oleh pemerintah untuk mengatasi permasalahan perpajakan. Pada tahun 1984, Pemerintah telah melakukan reformasi terhadap sistem perpajakan Indonesia dari official assessment system menjadi self assesment system guna meningkatkan penerimaan negara. Menurut Tarjo \& Kusumawati (2006), kebijakan bagus yang dibuat oleh pemerintah dengan memberikan kepercayaan penuh kepada wajib pajak untuk menghitung, menyetor, melaporkan sendiri pajak terutangnya mempunyai kelemahan dimana kebijakan ini sering kali disalahgunakan oleh wajib pajak itu sendiri. Faktanya, penerimaan

\footnotetext{
* Kontak Penulis:

Email: umaimah@umg.ac.id

Institusi: Universitas Muhammadiyah Gresik
} 
negara yang dapat dikatakan masih rendah dikarenakan adanya fenomena kelalaian dan kecurangan wajib pajak dalam melaksanakan kewajiban perpajakan (Ivon Trisnayanti \& Jati, 2015). Hingga pada saat itu pemerintah membuat program guna meningkatkan kepatuhan wajib pajak khususnya dalam pelaporan harta. Program tersebut bernama Tax Amnesty yang pelaksanaannya diawasi langsung oleh Bapak Presiden Republik Indonesia yaitu Joko Widodo. Sayangnya menurut Primadhyta (2017) pencapaian dari program tersebut dapat dikatakan belum berhasil atau bahkan jauh dari target. Hal ini dapat dilihat dari data tingkat partisipasi dimana dari 32,7 juta wajib pajak yang mempunyai NPWP, hanya 956 ribu wajib pajak atau sekitar 2,9\% yang mengikuti kegiatan tersebut. Data ini membuat beberapa pengamat salah satunya Center of Reform Economic (CORE) menilai bahwa program tax amnesty yang dicanangkan pemerintah belum berhasil dan masih banyak Wajib Pajak yang belum melaporkan harta secara sukarela dan terbuka.

Enggannya pelaporan harta oleh wajib pajak menarik untuk dikaji. Salah satu pegawai direktorat jenderal pajak Lisa Amalia Artistry Ramadhani, n.d. pernah menyampaikan bahwa rata-rata wajib pajak yang berbondong-bondong untuk melaksanakan kewajiban perpajakannya dengan melaporkan SPT Tahunan seringkali memberikan pernyataan bahwa harta yang dimilikinya tidak ada yang berharga. Sehingga mereka berpikir untuk tidak mencantumkan dalam SPT Tahunan. Padahal banyak sekali contoh harta yang perlu ditambahkan dalam SPT Tahunan seperti sepeda motor. Hampir semua orang memiliki sepeda motor mengingat teknologi saat ini semakin berkembang. Bahkan hal yang lebih mengejutkan lagi ketika membicarakan pelaporan harta, wajib pajak yang enggan dan takut untuk melaporkan hartanya akan melakukan segala cara supaya bisa menghindari pelaporan harta. Mereka bahkan bisa saja menggunakan nama orang lain seperti orang tua, kerabat atau anaknya atas harta yang mereka punya.

Hal ini sejalan dengan pengalaman penulis saat menjalankan tugas sebagai relawan pajak di KPP Pratama Gresik Utara. Kurangnya pemahaman wajib pajak mengenai sistem eFilling dan minimnya fiskus pajak membawa penulis menjadi relawan pajak tentunya dengan persyaratan dan kualifikasi yang ketat. Penulis yang saat itu menjadi relawan bertugas membantu dalam hal penyampaian SPT Tahunan pribadi melalui sistem e-Filling. (Halim et al., 2015) menjelaskan bahwa SPT (Surat Pemberitahuan) merupakan surat yang digunakan oleh wajib pajak untuk melaporkan perhitungan dan pembayaran pajak, objek pajak atau bukan objek pajak, serta harta dan kewajiban sesuai dengan ketentuan perundang-undangan yang berlaku.

Sesuai dengan ketentuan dan arahan dari fiskus pajak, relawan pajak membimbing wajib pajak penghasilan untuk melakukan pengisian komponen-komponen yang ada dalam sistem $e$-Filling secara runtut dan lengkap. Namun dalam prakteknya saat mengisi komponenkomponen dalam sistem e-Filling, penulis merasa heran karena rata-rata wajib pajak yang dibantu terkesan tidak mau dan takut untuk menyampaikan harta yang dimiliki. Ada pula yang bertanya harta apa saja yang seharusnya dimasukkan dalam SPT Tahunan. Padahal sudah merupakan kewajiban bagi wajib pajak untuk melaporkan harta serta hutang yang dimilikinya dalam sistem e-Filling secara jujur, sukarela, dan terbuka.

Beberapa fiskus pajak pun merasa demikian. Mereka yang ada di KPP pun sudah menyerukan dan menekankan kepada wajib pajak untuk melaporkan hartanya. Fiskus pajak pun heran melihat gelagat wajib pajak yang terlihat takut ketika diminta untuk mengisi kolom harta pada SPT Tahunan. Pasalnya pengisian harta itu tidak akan mempengaruhi besarnya pajak yang dibayarkan oleh wajib pajak tetapi hanya untuk mencocokkan profil wajib pajak dengan penghasilan dan harta yang dimiliki oleh wajib pajak. Berdasarkan uraian diatas, penelitian-penelitian terdahulu belum memberikan jawaban mengenai ketakutan atau fobia wajib pajak untuk mengungkap harta yang dimilikinya. Penelitian tersebut berkutat mengenai fenomena pengungkapan harta wajib pajak pada SPT Tahunan. Maka dari itu, penelitian ini dimaksudkan untuk mencari makna ketakutan atau fobia wajib pajak untuk mengungkapkan hartanya dalam perspektif wajib pajak dan konsultan pajak.

Berdasarkan uraian dari latar belakang diatas, maka rumusan masalah dalam penelitian ini adalah "Bagaimana memaknai fobia atau ketakutan wajib pajak untuk mengungkapkan hartanya dalam perspektif konsultan dan wajib pajak orang pribadi ?" 


\section{Tinjauan Pustaka}

\subsection{Fenomenologi Transendental}

Fenomenologi atau dalam bahasa Yunani disebut phaenesthai mengandung arti menunjukkan dirinya sendiri. Istilah lainnya adalah phainomenon yang secara harfiah mengandung arti "gejala" atau sesuatu yang nampak atau menampakkan diri sehingga bagi pengamat terlihat nyata. Fenomenologi digagas dan dikembangkan secara continue oleh Edmund Husserl yang biasa disebut sebagai Bapak Fenomenologi sebagai suatu kajian filsafat (1859-1938). Fenomenologi yang dicetus oleh Husserl adalah suatu pengetahuan yang menghadirkan kesadaran atas diri sendiri. (Hasbiansyah, 2008). Fenomenologi saat ini berkembang dan sudah banyak digunakan sebagai sebuah metode riset atau pendekatan penelitian di berbagai ilmu sosial (Hasbiansyah, 2008). Fenomenologi itu merupakan suatu bagian dari riset kualitatif yang murni dimana dalam implementasinya berdasarkan pada usaha dalam menelaah dan mendeskripsikan ciri-ciri intrinsik dari suatu gejala atau fenomena sebagaimana yang terjadi (J. Creswell, 2012). Secara mendalam, asumsi mengenai filosofi fenomenologi memaparkan bahwa manusia mengalami sebuah pengalaman hidup dengan penuh kesadaran.

Fenomenologi transendental merupakan fenomenologi yang paling dominan karena sering digunakan dalam penelitian ilmu sosial. Kata transendental mengandung arti "berada di luar kemampuan manusia; utama". Transendental yang dimaksud merupakan suatu kesadaran yang murni dari "Aku" yang mengalami fenomena atau gejala. Edmund Husserl memfokuskan fenomenologi transendental sebagai suatu studi kesadaran (A Kamayanti, 2016). Bagi Husserl, kesadaran memiliki peranan penting dari semua kegiatan berfilsafat sebagaimana yang disampaikan Descartes. Namun selain belajar dari Descartes, Husserl juga mempelajari teori kesadaran milik Immanuel Kant bahwa kesadaran itu harus berfokus pada isi kesadaran itu sendiri (Gahral, 2010:25).

Fenomenologi menurut Husserl merupakan sebuah struktur dari pengalaman sadar, maksudnya adalah dalam setiap pengalaman subyektif setiap individu, terdapat perwujudan dari realitas objektif. Jika disederhanakan, Dalam kehidupan sehari-hari, fenomenologi memfokuskan diri pada makna subjektif dari realitas objektif yang ada. Dalam tataran ini dualisme yang ada antara subjektivitas dan objektivitas coba diatasi oleh Husserl. Husserl menjelaskan bahwa subjektifitas bukanlah suatu hal yang harus dihindari. Lebih lanjut Husserl menjelaskan bahwa apa yang subjektif sebaiknya tidak ditandingkan dengan apa yang objektif. Subjektivitas menurut Husserl merupakan sebuah kesadaran dan kesadaran yang dimaksud akan mengatur atau menentukan objektivitas (Gahral, 2010:35).

Untuk dapat merepresentasikan hasil penelitian dengan analisis fenomenologi, (A Kamayanti, 2016) menjelaskan ada 5 unsur fenomenologi yang harus dipahami oleh fenomenolog diantaranya Noema, Noesis, Epoche (Bracketing), Intentional Analysis, dan Eidetic Reduction. Analisis yang pertama dimulai dengan mengidentifikasi apa yang nampak (Noema). Proses ini disebut juga dengan analisis tekstural. Berdasarkan Noema yang nampak, peneliti melakukan bracketing dimana peneliti harus memberikan tanda kurung atas apa yang didapatkan. Melalui proses bracketing pada noema peneliti akan mendapatkan makna yang lebih dalam dari Noema yaitu Noesis. Tahap selanjutnya yaitu intentional analysis dimana dalam tahap ini peneliti harus memahami tentang bagaimana proses bracketing dapat mengungkap bagaimana Noesis membentuk Noema. Jika secara runtut proses tersebut telah dilakukan, maka peneliti bisa mendapatkan eidetic reduction.

\subsection{Fobia Wajib Pajak Untuk Mengungkapkan Harta}

Seperti hal yang sebelumnya diulas, fenomena yang terjadi saat ini sesuai dengan pengalaman penulis adalah banyaknya wajib pajak yang enggan untuk patuh terhadap ketentuan perpajakan khususnya dalam pelaporan harta dalam SPT Tahunan. Padahal, wajib pajak orang pribadi seharusnya tau kewajiban seorang wajib pajak yaitu membayar pajak dan melaporkan kewajibannya pada SPT. Salah satu komponen yang harus dilaporkan adalah harta (Fikriningrum \& Syafruddin, 2012). Ketakutan wajib pajak yang seringkali diamati oleh petugas DJP nyatanya memang terjadi. Fenomena atau gejala penolakan atas pelaporan harta dalam SPT yang dilakukan oleh wajib pajak orang pribadi yang ingin diulas oleh peneliti ini 
dalam pandangan peneliti merupakan bentuk ketakutan berlebihan atau yang biasa disebut dengan Fobia.

Menurut KBBI, Fobia adalah ketakutan yang sangat berlebihan atas sesuatu. Sejalan dengan itu, dalam ilmu psikologi fobia merupakan suatu kondisi akan ketakutan yang abnormal (Kamayanti, 2016). Mendiskusikan mengenai fobia, orang-orang yang mengalami fobia akan merasakan kecemasan, overthinking atau bahkan merasa bahwa hidupnya penuh dengan dugaan-dugaan yang belum tentu benarnya. Akan tetapi fobia itu tidak identik dengan sesuatu yang menakutkan artinya fobia itu bisa terjadi pada suatu hal yang lazim. Kalau boleh mengambil contoh lain Raffi Ahmad salah satu artis ternama indonesia mempunyai fobia pada buah rambutan. Padahal sebenarnya rambutan merupakan sesuatu yang harfiahnya memang tidak menakuti. Orang-orang yang mempunyai fobia cenderung akan mencari segala cara untuk menjauhi hal yang ditakutinya. Raffi Ahmad mungkin punya cara dengan tidak melihat rambutan agar dirinya merasa aman. Jika dikaitkan dengan topik yang kita bahas, maka wajib pajak juga bisa mencari cara-cara untuk bisa menghindari pelaporan harta, contohnya dengan memberi nama orang lain pada aset yang dimilikinya, atau mungkin mengaku tidak mempunyai harta yang berharga.

Salah satu petugas yang pernah memberikan gambaran mengenai fenomena ketakutan ini mengatakan bahwa kesalahan persepsi seringkali terjadi di masyarakat. Wajib pajak takut jika kolom harta diisi secara jujur maka nanti pajak yang terutang akan bertambah. Berdasarkan pengalaman yang saya dapat ketika menjadi relawan pajak, wajib pajak yang takut untuk mengungkapkan hartanya akan bertindak seolah-olah tidak mempunyai harta yang berharga. Jika dalam keadaan terdesak, wajib pajak hanya akan memberitahukan hartanya seadanya tidak seluruhnya. Ada pula yang mengklaim bahwa mereka tidak mempunyai harta dan hanya punya hutang. Padahal sangat memungkinkan bagi wajib pajak mempunyai harta yang nilainya berharga seperti bangunan, tabungan, emas, tanah dan lain sebagainya. Fobia wajib pajak dalam mengungkapkan hartanya merupakan sebuah ungkapan yang dirasa oleh peneliti tepat menggambarkan fenomena yang sedang terjadi.

\subsection{Kerangka Berpikir}

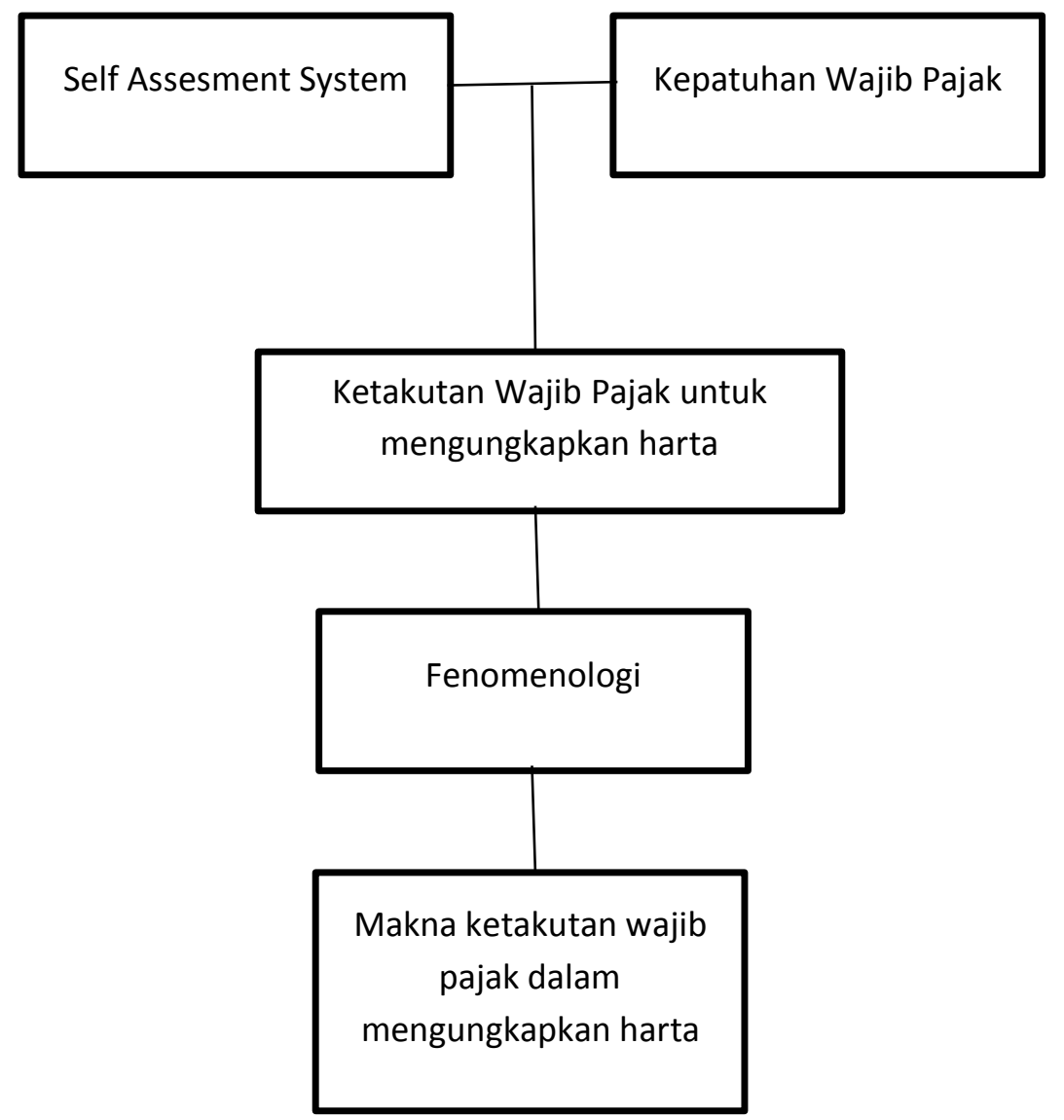




\section{Metodologi Penelitian}

\subsection{Jenis dan Pendekatan Penelitian}

Penelitian yang akan saya ambil ini menggunakan pendekatan kualitatif. Pendekatan kualitatif ini merupakan pendekatan penelitian yang orientasinya bukan berfokus pada angka atau numerik melainkan berfokus pada penjelasan atau pemaparan makna terhadap realita sosial atau pengalaman hidup individu yang terjadi. Penelitian ini berusaha menjelaskan dan menggambarkan suatu fenomena yang didasarkan pada pengalaman individu seseorang atau sekelompok orang. Penelitian kualitatif memiliki sifat yang alamiah karena hasil penelitiannya didapatkan melalui sumbernya secara langsung dan tidak dapat dilakukan melalui perantara apapun.

Penelitian ini menggunakan metode fenomenologi. Fenomenologi merupakan pandangan dalam berpikir yang menekankan fokus kepada pengalaman-pengalaman subjektif individu dan interpretasi-interpretasi dunia (Moleong, 2017). Fenomenologi yang digunakan dalam penelitian ini adalah fenomenologi transendental.

\subsection{Lokasi Penelitian}

Lokasi penelitian merupakan tempat suatu penelitian dilaksanakan atau dengan kata lain tempat untuk pengambilan data dilakukan. Dalam penelitian, penetapan lokasi ini perlu dilakukan dalam tahap awal penelitian guna mempermudah peneliti mengambil data penelitian. Lokasi penelitian dilakukan di wilayah Gresik dan Surabaya. Pengambilan data atau informasi dari informan yaitu fiskus pajak dilakukan di Gresik tepatnya di warung kopi daerah GKB. Pengambilan data atau informasi dari informan kedua yaitu konsultan pajak dilakukan di kantor tempat konsultan pajak bekerja. Sedangkan pengambilan data atau informasi dari informan yang lain yakni wajib pajak dilakukan di salah satu foodcourt di Surabaya. Hal ini dikarenakan terbatasnya wajib pajak orang pribadi di daerah Gresik yang enggan untuk dijadikan informan.

\subsection{Informan Penelitian}

Informan penelitian merupakan orang yang penting dalam penelitian kualitatif karena data yang dibutuhkan oleh peneliti berasal dari seorang informan. Informan dalam penelitian ini adalah fiskus pajak, konsultan pajak dan wajib pajak orang pribadi baik wajib pajak yang belum pernah mengikuti tax amnesty ataupun yang sudah pernah mengikuti kegiatan tax amnesty. Ketiga informan tersebut merupakan subjek yang paling representatif untuk memberikan informasi mengenai ketakutan atau "Fobia" wajib pajak untuk menguak hartanya

dalam SPT tahunan. Peneliti memilih fiskus pajak sebagai informan karena fiskus pajak merupakan subjek yang menghadapi dan mengamati secara langsung sikap dari wajib pajak. Peneliti memilih konsultan pajak sebagai informan karena konsultan pajak merupakan orang yang paham benar mengenai perpajakan. Sedangkan peneliti memilih wajib pajak sebagai informan karena wajib pajak merupakan subjek yang diteliti dimana wajib pajak ini yang mengalami rasa takut untuk menguak hartanya pada SPT tahunan.

\subsection{Sumber dan Jenis Data}

Penelitian ini memerlukan data yang sifatnya mendalam. Data dalam penelitian ini adalah data primer yaitu data yang diperoleh secara langsung dari informan yakni fiskus pajak dan wajib pajak baik wajib pajak yang belum pernah mengikuti tax amnesty ataupun yang sudah pernah mengikuti kegiatan tax amnesty dimana keduanya merupakan informan atau subjek penelitian yang punya pengalaman terkait dengan topik yang dibahas. Sedangkan jenis data yang digunakan untuk memperoleh hasil penelitian adalah data subyek dimana data yang diperoleh merupakan pendapat, sikap, pengalaman, atau karakter dari fiskus pajak dan wajib pajak baik wajib pajak yang belum pernah mengikuti tax amnesty ataupun yang sudah pernah mengikuti kegiatan tax amnesty. 


\subsection{Teknik Pengumpulan Data}

Salah satu hal yang sangat penting dalam penelitian adalah data karena data dapat menggambarkan hasil dari sebuah penelitian tersebut. Jadi, untuk memperoleh hasil yang maksimal, peneliti terlibat langsung dalam melakukan pengumpulan data. Dalam penelitian ini, pengumpulan data dilakukan dengan beberapa prosedur yaitu wawancara, observasi serta dokumentasi

\subsection{Teknik Analisis Data}

Tahap-tahap yang digunakan untuk menganalisis data dalam penelitian ini mengacu pada adaptasi dan modifikasi dari metode Stevick, Colaizzi, dan Keen dalam (Hasbiansyah, 2008) sebagai berikut :

1. Menentukan ruang lingkup fenomena yang akan diteliti: Peneliti berusaha mengerti dan memahami pandangan filosofis dibalik pendekatan yang digunakan, terutama konsep mengenai kajian bagaimana orang mengalami sebuah fenomena. Fenomena yang hendak dikaji melalui para informan ditetapkan oleh peneliti.

2. Menyusun draft pertanyaan: Peneliti menyusun dan menuliskan beberapa pertanyaan penelitian yang diharapkan dapat mengungkap makna pengalaman bagi para individu, serta menanyakan kepada mereka untuk menjelaskan pengalaman penting setiap harinya.

3. Pengumpulan data: Data dari individu yang mengalami fenomena yang diteliti dikumpulkan oleh peneliti. Data tersebut didapat melalui wawancara mendalam (in depth interview) dengan sekitar 1-5 orang. Tetapi jumlah ini bukan merupakan ukuran yang baku. Bisa saja subjek penelitiannya hanya beberapa orang. Teknik pengumpulan data lain yang dapat digunakan: observasi (langsung dan partisipan), penelusuran dokumen.

4. Analisis data: Peneliti melakukan analisis data fenomenologis. (a) Tahap awal: peneliti menjelaskan dan menggambarkan sepenuhnya fenomena yang dialami individu atau informan. Seluruh rekaman hasil wawancara mendalam dengan subjek penelitian ditranskripsikan ke dalam bahasa tulisan; (b) Tahap Horizonalization: dari hasil rekaman yang telah ditranskripsi, peneliti menginventarisasi pernyataan- pernyataan penting yang relevan dengan topik. Pada tahap ini, peneliti harus menunda penilaian (bracketing/ epoche); artinya, unsur subjektivitasnya jangan mencampuri upaya merinci point-point penting, sebagai data penelitian, yang diperoleh dari hasil wawancara tadi; (c) Tahap Cluster of Meaning: Selanjutnya peneliti mengklasifikasikan pernyataan- pernyataan tadi ke dalam tema-tema atau unit- unit makna, serta menyisihkan pernyataan yang tumpang tindih atau berulang-ulang. Pada tahap ini, dilakukan: (a) Textural description (deskripsi tekstural): Peneliti menuliskan apa yang dialami, yakni deskripsi tentang apa yang dialami individu; (b) Structural description (deskripsi struktural): Penulis menuliskan bagaimana fenomena itu dialami oleh para individu. Peneliti juga mencari segala makna yang mungkin berdasarkan refleksi si peneliti sendiri, berupa opini, penilaian, perasaan, harapan subjek penelitian tentang fenomena yang dialaminya.

5. Tahap deskripsi esensi : peneliti mengonstruksi (membangun) deskripsi menyeluruh mengenai makna dan esensi pengalaman para subjek.

6. Peneliti melaporkan hasil penelitiannya. Laporan ini memberikan pemahman yang lebih baik kepada pembaca tentang bagaimana seseorang mengalami sesuatu fenomena. Laporan penelitian menunjukkan adanya kesatuan makna tunggal dari pengalaman, di mana seluruh pengalaman itu memiliki "struktur" yang penting.

\subsection{Pengujian Keabsahan Data}

Tahap akhir dari penelitian adalah menguji keabsahan data yang diperoleh dalam penelitian ini. Adapun langkah-langkah yang digunakan adalah membuat deskripsi yang kaya dan padat. Dalam hal ini, peneliti harus bisa menyajikan banyak perspektif atau sudut pandangan mengenai suatu tema sehingga hasilnya lebih realistis dan kaya. Selain itu peneliti juga melakukan member check kepada para informan. Prosedur ini akan menambah validitas dari sebuah penelitian. Selain itu penyajian Informasi yang berbeda juga nampak dalam penelitian ini. Dalam penelitian ini ada berbagai macam perspektif yang tidak bisa disatukan, sehingga 
peneliti mendapat informasi yang berbeda dan didapat subtema yang berbeda pula. Hal tersebut sangat mungkin menambah kredibilitas penelitian.

\section{Hasil Penelitian}

\subsection{Kalkulasi Untung Rugi}

Kita seringkali mendengar kata untung dan rugi dalam kehidupan sehari-hari. Adakalanya kita sebagai ciptaan Tuhan juga mempertimbangkan beberapa hal terkait dengan untung dan rugi. Kita sebagai manusia memposisikan diri untuk bisa selalu mendapatkan keuntungan.Seperti itulah kita dalam menjalani sebuah kehidupan.

Layaknya orang yang sedang melakukan transaksi perdagangan dimana kedua belah pihak berharap untuk mendapatkan keuntungan dan menghindari kerugian, begitu pula ikatan antara wajib pajak dan juga negara. Ketika wajib pajak membayar dan melaporkan hartanya, wajib pajak ingin mendapat keuntungan yang dapat dimiliki seperti mendapatkan balasan hak atas apa yang telah dilakukan. Disisi lain, negara sendiri juga ingin mendapatkan keuntungan dari wajib pajak yang sudah membayar dan melaporkan hartanya. Negara berharap wajib pajak bisa memberikan sumbangan yang sifatnya terpaksa yang digunakan untuk kemakmuran bersama dan keterbukaan informasi akan harta yang dimiliki sebagai bentuk patuh wajib pajak kepada negara. Dalam hal lain ketika wajib pajak jujur dalam melaporkan harta yang mereka miliki, negara akan mendapat pendapatan dari pajak yang sesuai dengan keadaan yang sebenarnya. Dalam praktik perpajakan, nampaknya kalkulasi untung atau rugi ini merupakan salah satu hal yang masih diterapkan oleh wajib pajak dan mungkin bisa dirasakan oleh sejumlah pengamat perpajakan. Tema ini merupakan salah satu hal yang bisa menggambarkan subtema-subtema yang sudah ditemukan dalam analisis sebelumya. Dimana dalam subtema-subtema yang sudah ditentukan akan dijelaskan mengenai berbagai praktik atau sebuah bentuk kalkulasi untung rugi yang dilakukan oleh wajib pajak.

\subsection{Kultur Penghindaran Pajak Yang Tinggi}

Berdasarkan ungkapan Bapak I yang notabene merupakan fiskus pajak, ketika berbicara mengenai fobia yang dirasakan oleh wajib pajak, Bapak I menuturkan bahwa fobia itu merupakan sebuah \{kebiasan\}(Noema) atau sebuah bentuk \{ikut-ikutan\}(Noema). Artinya ada kultur yang kurang baik dalam dunia perpajakan yang sudah diwariskan. Kebiasaan merupakan suatu bentuk kegiatan yang dilakukan secara berulang-ulang. Kebiasaan yang dimaksud Bapak I adalah kebiasaan yang timbul karena \{adanya contoh\} yang secara terus menerus digaungkan oleh orang-orang terdekat wajib pajak. Dengan adanya contoh dan afirmasi yang ditampakkan oleh orang-orang terdekat kepada wajib pajak, Bapak I merasa bahwa wajib pajak belum dan perlu mengetahui informasi detail mengenai alur pajak yang dibayarkan oleh wajib pajak. Pada tataran ini Bapak I secara sadar melihat bahwa masih ada \{ketidaksadaran\} dan \{ketidaktahuan\} sehingga wajib pajak masih menganut pada kultur kebiasaan dan ikut-ikutan. Kondisi ini merefleksikan kesadaran Bapak I saat membicarakan masalah mengapa wajib pajak menganut kultur yang kurang baik itu. Ungkapan kesadaran Bapak I tersebut didasarkan atas pernyataan beliau sebagai berikut :

"apa ya.. mungkin ee ketidaksadaran kemudian ketidaktahuan. Prosentasenya mungkin berapa persen berapa persen ya memang mangkanya sekarang KPP itu dibentuk ada $A R "$

Bapak I menjelaskan bahwa ketidaksadaran itu timbul karena wajib pajak yang enggan atau \{tidak mau membayar pajak terlalu banyak\} (intensional Analysis). Hal ini merupakan suatu contoh tindakan atau perilaku yang merepresentasikan bahwa wajib pajak tidak mau rugi dengan adanya kewajiban pelaporan harta ini. Ungkapan yang merepresentasikan intensi tersebut adalah sebagai berikut :

"ya yang pertama itu ya nggak mau bayar terlalu banyak, kedua dia sebenarnya pingin bayar terlalu banyak tapi ikut-ikutan. Lah balik lagi ikut-ikutan"

Berdasarkan ungkapan kesadaran Bapak I tersebut poin yang bisa dicermati adalah fobia yang dirasakan oleh wajib pajak dalam mengungkapkan harta tidak lain dikarenakan wajib pajak takut jika pengungkapan harta tersebut bisa merugikan wajib pajak itu sendiri. Dengan kata 
lain wajib pajak tidak mau membayar pajak tinggi dikarenakan pelaporan atau pengungkapan harta yang dilakukan.

\subsection{Fobia Yang Salah}

Berdasarkan ungkapan Bapak I yang notabene merupakan fiskus pajak, ketika berbicara mengenai fobia yang dirasakan oleh wajib pajak, Bapak I menuturkan bahwa fobia itu merupakan \{fobia yang salah\} (Noesis). Bapak I menambahkan bahwa fobia yang dimaksudkan itu tidak sesuai tempatnya. Fobia yang dirasakan oleh wajib pajak itu tak mempunyai alasan yang cukup kuat untuk bisa dikatakan bahwa fobia yang dirasakan itu benar. Berikut pernyataan Bapak I :

"karena data itu kan banyak ya jadi kantor pajak itu dapat data dari instansi mana aja jadi kalau belum melaporkan pajaknya secara wajar itu pasti ada data yang masuk ke kita. Nah kenapa saya arahkan kesana. Harusnya fobianya yang benar itu seperti itu bukan fobia dia malah nggak nyampein gak ngungkapin harta sebenarnya. Fobia yang salah sebenarnya.

Dalam hal ini Bapak I menganggap bahwa wajib pajak seharusnya tidak takut untuk melaporkan hartanya tetapi wajib pajak seharusnya takut ketika fiskus pajak menemukan data bahwa wajib pajak tidak melaporkan hartanya secara jujur dan terang-terangan. Karena pada dasarnya harta yang dilaporkan wajib pajak itu digunakan sebagai kelengkapan informasi dan pencocokan data dengan penghasilan yang didapat oleh wajib pajak. Opini ini layak diberikan karena seperti yang kita tahu, jika harta tersebut tidak dilaporkan dalam SPT Tahunan dan suatu saat akan ditemukan keberadaanya oleh Dirjen Pajak, maka harta tersebut dianggap sebagai penghasilan dan tidak tanggung-tanggung, sanksi yang dikenakan mencapai 200\%. Hal ini tentu akan sangat merugikan wajib pajak. Ini merupakan suatu hal yang harus dipertimbangkan oleh wajib pajak.

\subsection{Bersedia Lapor Jika Diuntungkan}

Hal yang cukup menarik ketika peneliti berdiskusi mengenai fobia wajib pajak dalam mengungkapkan harta. Berdasarkan pengalamannya selama menjadi wajib pajak, Ibu D pernah merasakan fobia atau ketakutan yang tengah dibahas. Ibu D menuturkan bahwa ketakutan yang dialaminya dikarenakan \{faktor internal dan faktor eksternal\} (Noema). Kedua faktor ini dijelaskan lebih lanjut oleh Ibu D, bahwa faktor eksternal yang dimaksud adalah informasi yang didapat dari orang lain seringkali bernada negatif bagi pajak. Artinya orang-orang yang ditemui Ibu D dalam kehidupannya seringkali memberitahu hal-hal negatif tentang pajak yang sebenarnya belum dipastikan kebenarannya sehingga menyebabkan Ibu D mengambil keputusan untuk tidak melaporkan hartanya. Sedangkan faktor internal yang dimaksut Ibu D yaitu memang secara psikologis wajib pajak takut untuk melaporkan hartanya karena informasi yang didapat oleh Ibu D terbatas sehingga Ibu D mempertanyakan kegunaan dari pelaporan harta tersebut. Ibu D merasa bahwa selama Ibu D belum mengetahui dan mendapatkan informasi yang tepat mengenai implikasi dari pelaporan harta, maka bukan merupakan sebuah keharusan bagi Ibu D untuk melaporkan hartanya. Pada tataran ini Ibu D menyadari bahwa hal yang dilakukan oleh Ibu D merupakan suatu hal yang \{perlu $\}$ (Noesis) dilakukan. Ibu D merasa bahwa ketika Ibu D mengetahui implikasi pelaporan harta tersebut bisa menguntungkan untuk beliau dengan kata lain pajak yang dibayarkan lebih rendah, maka tanpa ragu dan tanpa takut, ibu D akan melaporkan hartanya secara jujur dan terang-terangan. Seperti pernyataan Ibu D :

"kalau mungkin saya tau gunanya apa, bisa mengurangi pajak saya dimasa yang akan datang ya akhirnya saya laporkan" 
Berdasarkan ungkapan kesadaran Ibu D tersebut poin yang bisa dicermati adalah fobia yang dirasakan oleh Ibu D dengan sepak terjangnya sebagai wajib pajak perlu dilakukan. Dalam hal ini "Aku" mengungkapkan urgensi dari perilakunya tersebut dikarenakan keterbatasan informasi terkait dengan implikasi dari pelaporan harta dalam SPT tahunan. "Aku" merasa bahwa seandainya "Aku" mengetahui keuntungan dari pelaporan harta tersebut dapat memperkecil nominal pajak yang dibayarkan, maka dengan senang hati Ibu D akan melaporkan hartanya. Dalam hal ini dibalik fobia yang dihadapi ibu D, ada kalkulasi untung atau rugi yang harus dipertimbangkan oleh ibu D ketika akan melaporkan hartanya.

\subsection{Bentuk Ketidakpercayaan Wajib Pajak Terhadap Pemerintah}

Berdasarkan pengalaman Ibu D ketika mengikuti Tax Amnesty, ketika berbicara mengenai fobia wajib pajak, ibu D mengungkapkan bahwa tax amnesty belum sepenuhnya dapat mengobati fobia yang dirasakan oleh wajib pajak dalam mengungkapkan harta. Ibu D menambahkan bahwa masih ada unsur ketidakpercayaan \{untrust\}(Noema) yang dirasakan oleh wajib pajak. Ketidakpercayaan ini kemungkinan timbul karena melihat \{situasi politik ekonomi\} dinegara kita dimana masih maraknya korupsi yang dilakukan oleh pejabat negara. Disini peneliti dapat menangkap kesadaran "Aku" yang berada pada situasi yang resah dan mengalami trauma karena pengelolaan pajak oleh pemerintah kerap kali dibumbui dengan korupsi besar-besaran. Hal ini tentunya membuat Ibu D merasa dirugikan dan takut untuk melaporkan hartanya karena pajak yang dibayarkan atau harta yang dilaporkan oleh ibu D disalahgunakan oleh beberapa oknum. Berikut ungkapan Noema yang secara gamblang menggambarkan sedikit mengenai tax amnesty:

"nggak sepenuhnya sih, secara psikologis orang kayak untrust gitu kan. Soalnya gini kadang-kadang ngapain sih aku harus bayar pajak banyak-banyak. Kenapa sih kan disana juga banyak orang yang korupsi. Banyak kan yang kadang-kadang gitu. Aku tuh nggak ikhlas bayar pajak. Adaloh temenku kayak gitu dia bilang gini mbok laporno kabeh? iyolah. Sing anyar-anyar iyo.gendeng pek, lek aku yo males pek. Aku sak hartahartaku iku males dilaporno, gae opo. Toh aku lo tetep mbayar. Mbayar iku gawe opo. Kan gitu."

Ibu D menganggap pajak merupakan sebuah pemaksaan bukan merupakan sebuah kewajiban karena dalam aturan perpajakan ada sanksi atau denda. Mendengar hal ini peneliti tertarik untuk mengkilas balik penelitian yang dilakukan oleh mahasiswa Universitas Muhammadiyah Gresik yang sebelumnya membahas mengenai Tax Amnesty. Pasalnya dalam penelitiannya, informan yang memberikan informasi dalam hal ini Bapak Heru selaku konsultan pajak memberikan pernyataan yang sama terkait anggapannya terhadap pajak, Bapak Heru mengatakan bahwa definisi dari pajak yang memiliki sifat memaksa inilah yang membuat wajib pajak tidak melaporkan harta ataupun hutang wajib pajak dengan kondisi yang sebenarnya bahkan wajib pajak cenderung untuk menghindari hal tersebut.

\subsection{Deklarasi Harta Sebagian : Cari aman}

Hal cukup mengejutkan juga muncul ketika membicarakan mengenai fobia wajib pajak dalam melaporkan harta. Saat disinggung dan diberikan opsi terkait pelaporan harta saat ini, dengan tegas Ibu D menjawab Ibu D akan melaporkan sebagian hartanya. Tindakan yang dilakukan oleh Ibu D bukan tanpa alasan. Ibu D menganggap bahwa jika Ibu D melaporkan secara langsung semua harta pada kondisi saat ini, fiskus pajak akan curiga dan mempertanyakan kejanggalan penambahan harta yang secara tiba-tiba tanpa diimbangi dengan pembayaran pajak yang sesuai. Artinya, Ibu D merasa \{lebih baik\} (Noesis) Ibu D melaporkan hartanya secara bertahap. Berikut merupakan pernyataan Ibu D:

\footnotetext{
"sebagian"

"sekarang \{nggak mungkin lah dari kita nggak ngelaporin sama sekali terus habis itu kita ngelaporin\} Ya mungkin dilaporin sebagian demi sebagian atau bertahap. Nanti fiskus
} 
akan berfikir bahwa loh \{berarti selama ini kamu punya laba ditahan banyak dong\}. Berarti kalau laba ditahannya banyak berarti kamu banyak yang nggak dilapor dong gitu dong."

Ibu D merasa hal itu perlu dilakukan oleh Ibu D. "Aku" merasa takut jika langsung melaporkan seluruh hartanya. "Aku" menjelaskan lebih lanjut ketakutannya itu didasari karena tidak mau terkena denda atau pembayaran yang lebih tinggi. Hal ini merupakan salah satu perwujudan kalkulasi untung atau rugi yang akan dilakukan oleh wajib pajak

\subsection{Ujian Keikhlasan}

Berdasarkan pengalaman Bapak Riyanto selama menjadi konsultan pajak, Bapak Riyanto mengamini dengan sadar bahwa fobia wajib pajak untuk mengungkapkan hartanya memang benar-benar \{ada\} (Noema). Lebih lanjut, Bapak Riyanto menjelaskan teknis dari ketidakpatuhan ini dilakukan secara cuma-cuma dengan \{tidak melaporkan hartanya begitu saja (Epoche). Wajib pajak pasrah akan konsekuensi yang dihadapi ketika timbul kasus baru terkait dengan pelaporan harta. Bapak Riyanto merasa bahwa sikap takut yang dirasakan itu merupakan suatu hal yang situasional, artinya pada tataran ini Bapak Riyanto menyadari bahwa ketakutan yang dirasakan oleh wajib pajak itu \{kadang perlu (Noesis) dilakukan. Karena jika dikembalikan lagi, semua itu tergantung pada niat pribadi masing-masing.

Selain dari niat, government juga turut mempengaruhi. Kepercayaan wajib pajak kepada pemerintah patut juga untuk dipertanyakan. Karena semua ini menyangkut hal yang sensitif yaitu uang. Pasalnya Bapak Riyanto menyatakan bahwa jika uang yang dikeluarkan oleh wajib pajak itu terhitung kecil, wajib pajak tidak akan mempermasalahkan. Tetapi jika uang yang dikeluarkan oleh wajib pajak itu besar, wajib pajak akan berpikir dua kali. Berikut pernyataan Bapak Riyanto yang menjelaskan tentang kalkulasi yang dilakukan oleh wajib pajak:

"Masalahnya kalau hal kecil sih orang langsung bayar. Tapi kalau besar keroso emane. Sama kayak zakat aja. Iya kan zakat kan menurut agama merupakan suatu rukun. Kalau sudah besar eman-eman akhire. Jadi ada orang zakatnya misalnya hartanya 1 triliun,zakatnya 250 juta eh 2,5 M contohnya. Pertanyaannya, mau ngeluarin nggak 2,5 M - jadi itu tergantung dari perspektif pribadinya, tergantung dari niatnya juga, tergantung dari lingkungan govermentnya juga. Nah govermentnya bisa nggak di pakai acuan jadi kalau negara-negara maju pemerintahannya adil dan sebagainya tentunya rakyatnya akan rela, kalau trustnya masyarakat pada pemerintahan masih rendah yo nggak rela.

\subsection{Pelaporan Harta sebagai Salah Satu Wujud Keimanan terhadap Tuhan}

Penelitian ini membahas mengenai kepatuhan perpajakan. Kepatuhan perpajakan dalam dimensi transendental atau dalam kaitannya dengan dimensi ketuhanan berkaitan erat dengan sebuah kewajiban yang dilakukan oleh wajib pajak untuk melaporkan hartanya. Kewajiban tersebut mengindikasikan sebuah kejujuran dalam hal pelaporan harta. Penghindaran, pelanggaran, Penolakan dan perbuatan yang tidak terpuji yang diungkapkan manusia merupakan salah satu bentuk ketidaktaatan manusia terhadap Tuhan.

Dalam kehidupan sehari-hari, kita sebagai manusia pasti pernah melakukan sebuah kesalahan sehingga nantinya akan timbul rasa bersalah kepada Tuhan dan mungkin berujung pada sebuah dosa. Salah satu contoh kecil dari perbuatan buruk yang dapat menimbulkan dosa adalah ketidakjujuran. Penelitian ini membahas mengenai kepatuhan perpajakan. Kepatuhan perpajakan dalam dimensi transendental atau dalam kaitannya dengan dimensi ketuhanan berkaitan erat dengan sebuah kewajiban yang dilakukan oleh wajib pajak untuk melaporkan hartanya. Kewajiban tersebut berkaitan erat dengan sebuah kejujuran. Jika dikaitkan dengan topik yang dibahas dalam penelitian ini, ketidakjujuran yang dimaksud adalah ketidakjujuran dalam hal pelaporan harta yang dilakukan oleh wajib pajak. Wajib pajak yang tidak jujur dalam melaporkan hartanya itu akan merasa bersalah karena telah menghianati kewajibannya sebagai seorang wajib pajak terhadap negara dan juga telah melupakan tanggung jawab moral kita baik kepada sesama, negara dan Tuhan. 


\subsection{Pelaporan Harta merupakan suatu Kewajiban yang Harus di selesaikan}

Ketika ditanya mengenai keterkaitan antara kepatuhan wajib pajak khususnya pelaporan harta dengan dimensi ketuhanan Bapak Riyanto memberikan statement yang cukup bijak. Bapak Riyanto menjelaskan bahwa ada keterkaitan antara pelaporan harta dengan keimanan kita terhadap Tuhan. Saat peneliti memberikan pertanyaan lebih dalam terkait teknis dari keterkaitannya Bapak Riyanto menjawab dengan singkat bahwa keterkaitannya ada ketika wajib pajak \{menyadari bahwa pelaporan itu merupakan suatu kewajiban\}(Epoche). \{Kewajiban tersebut harus diselesaikan\}(Noesis). Pada tataran ini dengan timbulnya kewajiban perpajakan, peneliti melihat adanya sebuah tanggung jawab yang dipikul oleh wajib pajak. Lebih lanjut Bapak Riyanto menjelaskan jika kewajiban tersebut tidak terselesaikan, maka wajib pajak akan dihantui dengan perasaan bersalah. Beliau menambahkan terkait dosa yang didapat oleh wajib pajak ketika kewajiban pelaporan harta itu tidak diselesaikan, Tuhan dan pasukannya yang akan menghakimi sendiri. Peneliti memiliki spekulasi bahwa perasaan bersalah ini ditujukan bukan hanya kepada negara tetapi juga kepada Tuhan. Berikut pernyataan Bapak Riyanto terkait dengan pandangannya tentang pelaporan jika dilihat dari dimensi ketuhanan:

\section{"kalau itu sebuah kewajiban ya harus diselesaikan" \\ "ya dia merasa bersalah tapi untuk masalah dosa kan sudah ada hakime" \\ (ya dia merasa bersalah tapi untuk masalah dosa kan sudah ada hakimnya)}

\subsection{Fobia Merupakan Cerminan dari sebuah Dosa}

Hal yang cukup menohok dijelaskan oleh Bapak I ketika ditanya mengenai fobia wajib pajak dalam mengungkapkan harta jika dikaitkan dengan dimensi transendental atau keimanan kita terhadap Tuhan. Bapak I menjelaskan bahwa karena kepatuhan itu merupakan indikasi dari kejujuran, maka kejujuran merupakan salah satu indikator \{penting\} (Noesis) dalam dunia perpajakan karena saat ini sistem perpajakan menggunakan self assesment system dimana wajib pajak diharuskan jujur dalam menghitung, membayar dan melaporkan pajaknya.

Bapak I menambahkan bahwa orang yang tidak melaporkan hartanya sepatutnya orang yang melakukan dosa karena jika dikaitkan orang yang tidak melaporkan hartanya bisa dikatakan tidak jujur kepada negara. Dan ketidakjujuran itu merupakan perbuatan yang dapat menyebabkan dosa. Berikut pernyataan Bapak I:

"Ya sepatutnya orang yang melakukan dosa ya. Ketika orang melakukan dosa, orang tidak melaporkan harta di SPTnya, itu kan dosa ya. Ketidakjujuran itu kan dosa ya. Jadi arahya mungkin kesana. Tanggung jawab moral ya. Uang saya bisa saya jadikan ibadah buat saya tapi melalui negara. Jadi bayar pajak kan ibadah ya. Kok saya bohongi dengan tidak melaporkan secara benar moralnya kesana."

Fobia yang dirasakan oleh wajib pajak tentunya akan menimbulkan dampak yang negatif jika terus menerus ada. Fobia yang dialami oleh wajib pajak dapat membuat wajib pajak resah sehingga membuat keputusan untuk tidak melaporkan hartanya. Dalam hal ini fobia yang dirasakan oleh wajib pajak bisa saja mengantarkan pada sebuah dosa atau merupakan cerminan dari sebuah dosa karena ketidak jujurannya dalam pelaporan harta.

\section{Kesimpulan Dan Saran}

Berdasarkan uraian yang telah disampaikan diatas, dapat disimpulkan bahwa didapatkan makna dari fobia yang dirasakan oleh wajib pajak dalam mengungkapkan harta yakni bentuk kalkulasi untung rugi dan sebuah cerminan keimanan wajib pajak. 
Kedua tema tersebut dijadikan peneliti menjadi satu tema besar yang berjudul "Praktik bisnis dengan negara yang dinilai Tuhan". Ketika orang-orang berbisnis pasti memperhitungkan untung dan rugi yang akan didapat, sama halnya dengan wajib pajak yang berbisnis dengan negara melalui pajak. Wajib pajak akan memperhitungkan atau mengkalkulasikan untung atau rugi yang didapat. Namun tidak terbatas itu praktik bisnis dengan negara ini dinilai oleh Tuhan dengan melihat keimanan wajib pajak. Artinya ketika fobia wajib pajak berkemungkinan besar menyebabkan ketidakpatuhan wajib pajak dalam hal ini kewajiban melaporkan harta tidak dijalankan maka keimanan wajib pajak patut dipertanyakan.

Penelitian ini seharusnya membutuhkan waktu yang cukup lama agar hasil yang didapat bisa lebih mendalam. Peneliti mengharapkan adanya penelitian lanjutan dengan menggunakan metodologi studi kasus sehingga dapat mengetahui makna fobia wajib pajak dengan metode yang berbeda. Selain itu peneliti mengharapkan agar penelitian selanjutnya bisa menambah jumlah informan sehingga hasil penelitian lebih kaya akan realitas yang ada.

\section{Referensi}

Akbar, I. N. (2015). Pengaruh Persepsi Wajib Pajak Orang Pribadi terhadap Pelaksanaan Self Assessment System. Nhk技研, 151(1), 10-17. https://doi.org/10.1145/3132847.3132886

Bungin, B. (2001). Metode Penelitian Kualitatif , Aktualisasi Metodologis ke Arah Ragam Varian Kontemporer. In PT RajaGrafindo Persada.

Burrell, G., \& Morgan, G. (1979). Social Paradigms and Organisational Analysis. In Sociology The Journal of The British Sociological Association (Vol. 3, Issue 4). http://search.ebscohost.com/login.aspx?direct=true \&db=bth\&AN=5963638\&site=ehostlive

Cresswell, J. W. (2017). Research Design Pendekatan Kualitatif, Kuantitatif, dan Mixed Edisi ketiga. In Yogyakarta: Pustaka Pelajar.

Creswell, J. (2012). Qualitative Research Narrative Structure. pdf." Qualitative Inquiry and Research Design. In Choosing Among Five Approaches (pp. 220-230).

Creswell, J. (2013). Creswell (2013) Qualitative Research Narrative Structure.pdf. In Qualitative Inquiry and Research Design: Choosing Among Five Approaches, Third Edition.

Creswell, W. J. (2016). Penelitian Kualitatif dan Desain Riset, memilih diantara lima pendekatan" oleh John W. Creswell pustaka pelajar edisi 3. In Penelitian Kualitatif.

Diamastuti, E. (2018). Ekuitas: Jurnal Ekonomi dan Keuangan Ke (Tidak) Patuhan Wajib Pajak: Potret Self Assesment System. In EKUITAS (Jurnal Ekonomi dan Keuangan) (Vol. 20, Issue 3). www.pajak.go.id

Exploring phenomenology: a guide to the field and its literature. (1991). Choice Reviews Online, 28(06), 28-3098 - 28-3098. https://doi.org/10.5860/choice.28-3098

Fikriningrum, W. K., \& Syafruddin, M. (2012). Analisis Faktor-Faktor Yang Mempengaruhi Wajib Pajak Orang Pribadi Dalam Memenuhi Kewajiban Membayar Pajak (Studi Kasus Pada Kantor Pelayanan Pajak Pratama Semarang Candisari). Fakultas Ekonomika dan Bisnis.

Gahral, D. (2010). Pengantar Fenomenologi. penerbit koekoesan.

Halim, A., Bawono, I. R., \& Dara, A. (2015). Perpajakan (Konsep, Aplikasi, Contoh, dan Studi Kasus). In Penerbit Salemba Empat (Vol. 7, Issue 9).

Hasbiansyah, O. (2008). Pendekatan Fenomenologi: Pengantar Praktik Penelitian dalam Ilmu Sosial dan Komunikasi. Mediator: Jurnal Komunikasi, 9(1), 163-180. https://doi.org/10.29313/mediator.v9i1.1146

Hutagaol, J. (2007). Perpajakan: Isu-Isu Kontemporer. Jakarta: Graha Ilmu, 1(December), 18.

Indri, I. (2018). Perlakuan Pengungkapan Aset Sukarela (PAS) Final pada Wajib Pajak Orang Pribadi. Unika Soegidjarpranata Semarang.

Ivon Trisnayanti, I., \& Jati, I. (2015). Pengaruh Self Assesment System, Pemeriksaan Pajak, Dan Penagihan Pajak Pada Penerimaan Pajak Pertambahan Nilai (PPN). E-Jurnal Akuntansi, 13(1), 292-310.

Kamayanti, A. (2016). Fobi(A)Kuntansi: Puisisasi Dan Refleksi Hakikat. Jurnal Akuntansi Multiparadigma, 7(1). https://doi.org/10.18202/jamal.2016.04.7001 
Kamayanti, A. (2016). Metodologi Penelitian Kualitatif Akuntansi: Pengantar Religiositas Keilmuan. In Yayasan Rumah Peneleh.

Kesuma, A. I. (2016). Pengampunan Pajak (Tax Amnesty) Sebagai Upaya Optimalisasi Fungsi Pajak. Inovasi, 12(2), 270-280.

Kuncoro, Y. I. (2018). Pelaporan Pengungkapan Aset Sukarela Final Wajib Pajak Orang Pribadi Sesuai Peraturan Pemerintah Nomor 36 Tahun 2017. Unika Soegijapranata Semarang.

Kusuma, I. L., \& Dewi, M. W. (2018). Kebijakan Tax Amnesty: Suatu Peninjauan dalam Perspektif Etika Deontologi Sebagai Bentuk Pilihan Wajib Pajak dalam Melaksanakan Kewajiban Perpajakan. Jurnal Akuntansi Dan Pajak, 18(2), 204. https://doi.org/10.29040/jap.v18i2.118

Lisa Amalia Artistry Ramadhani. (n.d.). Tidak Mengisi Harta dengan benar, Ini sanksinya. Www.pajak.go.id. Retrieved December 25, 2020, from https://www.pajak.go.id/id/artikel/tidak-mengisi-harta-dengan-benar-ini-sanksinya

Moleong, L. J. (2017). Metodologi Penelitian Kualitatif (Edisi Revisi). In PT. Remaja Rosda Karya (p. 424).

Prasetya, D. (n.d.). Pengaruh Self Assesment System Pengisian SPT Tahunan Orang Pribadi Terhadap Ketaatan Pengungkapan Harta Wajib Pajak Pada Pelaporan Tax Amnesty.

Primadhyta, S. (2017). Core: Hasil Dari Tax Amnesty Jauh Dari Ekspektasi. Www.cnnindonesia.com.

Putera, A. D. (2017). 1.000 wajib pajak yang diduga belum lapor hartanya diperiksa ditjen pajak.

Www.kompas.com. https://ekonomi.kompas.com/read/2017/11/22/185306126/1000-wajib-pajak-yangdiduga-belum-lapor-hartanya-diperiksa-ditjen-pajak

Resmi, S. (2016). Perpajakan: Teori dan Kasus Edisi Revisi. In Salemba Empat.

Sekaran, U., \& Bougie. (2017). Metode Penelitian untuk Bisnis Pendekatan PengembanganKeahlian. In Metode Penelitian untuk Bisnis Pendekatan Pengembangan-Keahlian (pp. 53-79).

Setyaningsih, T., \& Okfitasari, A. (2016). Mengapa Wajib Pajak Mengikuti Tax Amnesty. Ekuitas: Jurnal Ekonomi Dan Keuangan, 20(4), 415-433.

Sugiyono. (2016). Memahami Penelitian Kualitatif. Bandung: Alfabeta.

Tarjo, \& Kusumawati, I. (2006). Analisis perilaku wajib pajak orang pribadi terhadap pelaksanaan self assessment system suatu studi di Bangkalan. Jurnal Akuntansi \& Auditing Indonesia, 10(1), 101-120. 